\title{
APONTAMENTOS ACERCA DA VALIDADE DA INTERCEPTAÇÃO TELEFÔNICA COMO MEIO DE OBTENÇ̃̃o DE PROVA NO PROCESSO PENAL: O ENTEDIMENTO DOS TRIBUNAIS SUPERIORES E AS PROPOSTAS DE ALTERAÇÃ̃o LEGISLATIVA
}

\author{
NOTES ABOUT THE VALIDITY OF TELEPHONE INTERCEPTION AS A \\ MEAN OF OBTAINING EVIDENCES IN CRIMINAL PROCEDURES: THE \\ VIEW OF THE SUPERIOR COURTS AND THE PROPOSALS TO AMEND \\ THE FEDERAL LAW
}

Adriane Pinto Rodrigues da Fonseca Pires*

Humberto de Sá Garay**

\begin{abstract}
RESUMO: O presente trabalho tem como tema a interceptação telefônica, meio excepcional para a obtenção de prova em processo penal. $O$ artigo pretende apontar, sob o viés constitucional e legal, os critérios de admissibilidade e validade desse procedimento, bem como referir o posicionamento dos Tribunais Superiores brasileiros no que respeita à legitimidade e à licitude da prova colhida via interceptação telefônica. Por fim, faz-se referência à proposta de alteração legislativa relacionada à matéria.
\end{abstract}

PALAVRAS-CHAVE: Interceptação telefônica. Lei nº 9.296/96. Prova. Processo penal. Alteração legislativa.

ABSTRACT: The current paper has as its subject the interception of telephone lines, exceptional mean of obtaining evidence in criminal proceedings. This article points to, under the constitutional and legal bias, the criteria for admissibility and validity of this procedure, as well as point out the position of the Superior Courts in Brazil regarding the acceptance of evidence gathered via telephone interception. Finally, the paper makes references about the proposals to amend the Federal Law on this matter.

KEYWORDS: Telephone interception. Federal Act no. 9296/96. Evidence. Criminal procedure. Amendment of the law.

" Mestranda em Ciências Criminais (PUCRS). Especialista em Direito Público (ESMAFE/IMED). E-mail: nanepintopires@gmail.com.

** Mestrando em Ciências Criminais (PUCRS). Especialista em Políticas e Gestão de Segurança Pública (UFRGS).E-mail: humbertogaray@hotmail.com. 


\section{INTRODUÇC̃̃̃}

A interceptação telefônica ${ }^{1}$ pode ser conceituada como "um ato de ingerência nas comunicações telefônicas alheias, quer com a finalidade de impedilas, quer com a finalidade de delas tomar conhecimento" (GRINOVER, 1982, p. 198). Consiste, pois, em um procedimento que representa exceção ao direito ao sigilo das comunicações telefônicas, o qual é assegurado pelo inciso XII, do artigo $5^{\circ}$, da Constituição da República Federativa do Brasil.

Constitui-se em um importante meio para a obtenção de prova no processo penal - tanto na fase preparatória como na incidental -, e, ao mesmo tempo, em uma restrição a um direito fundamental, a saber, o direito à intimidade da pessoa interceptada e daquelas com as quais esta se relaciona. Segundo Ada Grinover:

A questão das interceptações telefônicas faz parte de um problema mais amplo, atinente ao equilíbrio entre duas opostas exigências: a de tutelar o direito à intimidade e a de colocar à disposição do juiz um meio de investigação capaz de obter resultados genuínos e particularmente úteis, em uma época em que também a delinquência se organiza sob formas cada vez mais hábeis e complexas. (GRINOVER, 1982, p. 197).

O dispositivo constitucional que a prevê, referido alhures, estabeleceu que a autorização para a quebra do sigilo está reservada à decisão judicial e somente será decretada para fins de investigação criminal ou instrução processual penal, e na forma que a lei estabelecer (o ato normativo de que se fala é a Lei Federal $\mathbf{n}^{\circ}$ 9.296/96).

Nessa perspectiva, a validade da interceptação telefônica, como meio para a obtenção de prova, não prescinde da observância aos requisitos traçados pela Lei $\mathbf{n}^{\circ}$ 9.296/96, mas, especialmente, aos princípios constitucionais do devido processo legal, da inadmissibilidade das provas ilícitas e o da proporcionalidade, uma vez que apenas normas constitucionais ${ }^{2}$ (regras e princípios) possuem a aptidão de fundamentar a restrição a um direito fundamental.

Acerca de sua legitimidade, esta "há de, inequivocamente, brotar da persecução da finalidade máxima do processo penal - proteção dos direitos

1 A expressão “interceptação telefônica” é um gênero do qual fazem parte três espécies: as interceptações stricto sensu, que são verificáveis quando há um terceiro que viola a conversa entre duas ou mais pessoas sem o conhecimento destas, daí a necessidade de autorização judicial; a escuta telefônica, que ocorre na ocasião em que um terceiro viola a conversa entre duas ou mais pessoas com o conhecimento de uma delas; e a gravação telefônica, em que não há terceiro, mas sim a presença de um dos interlocutores, o qual registra a conversa que mantém com o outro. Ver AVOLIO (2003, p. 92).

2 Nesse sentido, ver ALEXY (1993, p. 272). 
fundamentais das pessoas" (VALENTE, 2008, p. 71). Em razão disso, parte-se da premissa de que "somente podem ser considerados atos de prova e, portanto, aptos a fundamentarem a sentença, aqueles praticados dentro do processo à luz da garantia da jurisdição e demais regras do devido processo legal" (LOPES JÚNIOR, 2012, p. 547).

Em síntese: em se tratando de medida restritiva a direito fundamental "somente pode ser deferida judicialmente a partir da obediência a um somatório de requisitos estabelecidos explicitamente na lei e na Constituição, além da observância dos princípios (explícitos e implícitos) da Lei Maior" (STRECK, 2001, p. 70).

\section{EXCURSO HISTÓRICO ACERCA DO REGRAMENTO CONSTITUCIONAL}

O sigilo das comunicações foi elevado ao estado (status) de garantia fundamental e, em razão disso, ostenta no ordenamento jurídico constitucional vigente, a condição cláusula pétrea, nos termos do artigo $60, \S^{\circ}{ }^{\circ}$, IV, da Constituição Federal $^{3}$. Tal situação implica, por exemplo, a vedação de que qualquer matéria tendente a aboli-lo possa ser objeto de proposta de emenda à Constituição. Corporificada está, pois, a "ideia de um limite do limite também para o legislador ordinário" (MENDES; COELHO; BRANCO, 2007, p. 309).

Por outro lado, vale destacar que esse reconhecimento não obsta que o próprio texto da Carta Magna, no inciso XII do artigo $5^{\circ}$, estabeleça uma exceção ao sigilo das comunicações telefônicas:

XII - é inviolável o sigilo da correspondência e das comunicações telegráficas, de dados e das comunicações telefônicas, salvo, no último caso, por ordem judicial, nas hipóteses e na forma que a lei estabelecer para fins de investigação criminal ou instrução processual penal ${ }^{4}$.

Como já referido, a interceptação telefônica consiste em uma captação ${ }^{5}$ de

3 Dispõe o artigo $60, \S 4^{\circ}$, inciso IV, da atual Constituição Federal, que não será objeto de deliberação a proposta de emenda tendente a abolir, dentre outras matérias, os direitos e garantias individuais. Disponível em: < http://www.planalto.gov.br/ccivil_03/Constituicao/Constituicao.htm>. Acesso em: 11 maio 2013.

4 Disponível em: <http://www.planalto.gov.br/ccivil_03/Constituicao/Constituicao.htm>. Acesso em: 1 maio 2013.

5 No dizer de Lênio Streck, "o sentido é o de captar a comunicação telefônica, tomar conhecimento, ter contato com o conteúdo dessa comunicação” (STRECK, 2001, p. 55). 
conversa alheia, feita por um terceiro e sem o conhecimento dos interlocutores.

Anteriormente à Constituição Federal de 1988, a esfera da intimidade era protegida de forma mais difusa. Fazendo-se um excurso histórico pelas Constituições brasileiras, verifica-se que o direito ao sigilo de correspondência e das comunicações tem sido constitucionalmente protegido desde a Constituição Imperial de 1824.

Esse regramento foi repetido nas Constituições de $1891^{6}$ e de $1934^{7}$, mas somente com o advento da Constituição de 1937 é que o direito à inviolabilidade das comunicações sofreu a primeira restrição. Em seu artigo $122, \S 6^{\circ}$, a Carta de 1937 previa que seria garantida, aos brasileiros e estrangeiros residentes no País, a inviolabilidade do domicílio e da correspondência, salvo as exceções expressas em lei ${ }^{8}$.

A Lei Fundamental de $1946^{9}$, a seu turno, volta a reproduzir em seu texto (artigo 141, $\S 6^{\circ}$ ) a proteção ao sigilo da correspondência nos exatos termos das Cartas de 1891 e de 1934.

Já a partir da Carta de $1967^{10}$, o sigilo de correspondência foi tutelado de forma mais abrangente. Adotou-se, na redação do artigo $153, \S 9^{\circ}$, uma concepção ampla, a qual abarcava a correspondência telefônica e/ou telegráfica.

Ao mesmo tempo, na seara infraconstitucional, vigia, desde 1962, o Código Brasileiro de Telecomunicações (Lei $\mathrm{n}^{\circ} 4.117 / 62$ ), cujo artigo 57 trazia a seguinte disposição:

Art. 57 - Não constitui violação de telecomunicação:

$[\cdots]$

II - o conhecimento dado:

[...]

6 Nos termos do artigo 72, § 18, da Carta de 1991, o sigilo de correspondência é inviolável. Disponível em: <http://www.planalto.gov.br/ccivil_03/Constituicao/Constituicao91.htm>. Acesso em: 14 maio 2013.

7 O artigo 113, § $8^{\circ}$, da Constituição de 1934, reproduz o artigo 72, § 18, da Carta Política anterior. Disponível em: <http://www.planalto.gov.br/ccivil_03/Constituicao/Constituicao34.htm>. Acesso em: 12 maio 2013.

${ }^{8}$ Esse dispositivo foi revogado em 1942 pelo Decreto $\mathrm{n}^{\circ}$ 10.358, que declarou o Estado de Guerra em todo o território nacional. Disponível em:<http:/www.planalto.gov.br/ccivil_03/Constituicao/ Constituicao37.htm>. Acesso em: 11 maio 2013.

9 Disponível em:<http://www.planalto.gov.br/ccivil_03/Constituicao/Constituicao46.htm>. Acesso em: 11 maio 2013.

${ }^{10}$ Dispunha o artigo $153, \S 9^{\circ}$, da Constituição Federal de 1967, que seria garantida a inviolabilidade do sigilo da correspondência e das comunicações telegráficas e telefônicas. Disponível em: $<$ http://www. planalto.gov.br/ccivil_03/Constituicao/Constituicao67.htm>. Acesso em: 11 maio 2013. 
e) ao juiz competente, mediante requisitação ou intimação deste.

Com a nova ordem constitucional pós-ditadura militar, os debates acerca da consonância do Código de Telecomunicações com a Carta Magna de 1988 ganharam relevo, pois não havia consenso acerca da compatibilização das delimitações fixadas pelo artigo $5^{\circ}$, XII, do texto constitucional com o dispositivo legal, referido alhures, que possibilitava amplo acesso às comunicações, sem qualquer exceção.

Sobre essa necessidade de conformação constitucional, Geraldo Prado acentua que:

É preciso, pois, situar o problema. Cuidamos do regime dos direitos, liberdades e garantias. Mais: tratamos da restrição ao exercício desses direitos. Assim, é intuitivo admitir que seja a metódica constitucional a base dogmática a servir de marco teórico, influenciando a aplicação de ferramenta jurídica cuja atuação nada mais é do que implementação dessas restrições. (PRADO, 2006, p. 22).

Partindo-se do texto constitucional, apura-se que a admissibilidade de eventual quebra do sigilo das comunicações telefônicas está condicionada à observância de requisitos expressamente elencados, a saber, ordem judicial, para fins de investigação criminal ou instrução processual penal. Está-se diante de uma reserva legal qualificada (MENDES; COELHO; BRANCO, 2007, p. 610).

A opção do legislador constituinte foi a de estabelecer critérios com o fim de delimitar as hipóteses em que a invasão da intimidade terá cabimento, uma vez que esse direito também passou a ser reconhecido pela Carta Magna, no artigo $5^{\circ}$, inciso $\mathrm{X}^{11}$, uma novidade da Carta Política atual.

Instado a se manifestar, o Supremo Tribunal Federal, por ocasião do julgamento do Habeas Corpus n ${ }^{0} 69.912^{12}$, ocorrido em 1993, firmou entendimento no sentido de que o Código Brasileiro de Telecomunicações não teria sido recepcionado pela Constituição de 1988. Os julgadores consideram, portanto, que, no momento em que foi autorizada a interceptação telefônica por parte da autoridade judiciária, inexistia lei que tornasse viável a quebra do sigilo nos termos exigidos pela nova ordem constitucional ${ }^{13}$.

${ }^{11}$ Nos termos do artigo $5^{\circ}$, inciso X, da Constituição de 1988: "são invioláveis a intimidade, a vida privada, a honra e a imagem das pessoas, assegurado o direito a indenização pelo dano material ou moral decorrente de sua violação". Disponível em:<http:/www.planalto.gov.br/ccivil_03/Constituicao/ Constituicao.htm>. Acesso em: 11 maio 2013.

12 STF, HC 69912, Rel. Min. Sepúlveda Pertence, Rel. p/ Acórdão: Min. Carlos Velloso, Tribunal Pleno, julgado em 30.06.1993, DJ 26.11.1993. Disponível em:<http://www.stf.jus.br/jurisprudencia>. Acesso em: 10 fev. 2013.

${ }^{13}$ Em outro julgado de 1996, o Supremo Tribunal Federal, por maioria de votos, assentou 
Desse modo, diante da ausência de previsão legal, a ordem judicial foi tida como inválida e, por conseguinte, a prova colhida por meio deste procedimento, foi considerada ilícita e, em razão disso, inadmissível no processo (nos termos do artigo $5^{\circ}$, LVI, da Constituição Federal).

Dada a vinculação do intérprete às normas constitucionais, "na comparação dos valores em jogo - o respeito às garantias individuais por um lado, e o interesse da sociedade em que os delitos sejam investigados por outro - deve-se dar-se primazia aos primeiros por tratar-se de diretrizes da Lei Suprema" (CARRIÓ, 2003, p. 231).

Nesse contexto, pode-se concluir que, entre os anos de 1988 e 1996, no direito brasileiro, em relação às interceptações telefônicas, não havia um regime legal estabelecido (embora a existência de lei já estivesse prevista constitucionalmente). Diante dessa omissão legislativa, as autorizações judiciais eram controvertidas, havia incursões duvidosas no âmbito da intimidade dos indivíduos, o que não atendia à exigência constitucional de respeito aos direitos fundamentais.

\section{2}

O REGIME LEGAL DA INTERCEPTAÇÃO TELEFÔNICA

\subsection{HIPÓTESES LEGAIS DE CABIMENTO}

Como referido anteriormente, com a superveniência do novo ordenamento constitucional, passou-se a conviver com uma espécie de vácuo legislativo em matéria de interceptação telefônica, o que causava empecilhos às atividades de investigação criminal e à instrução processual penal.

Assim, somente em 25 de julho de 1996, quase oito anos após a promulgação da Constituição Federal de 1988, sobreveio a Lei nº 9.296/96 para regulamentar a matéria relativa às interceptações telefônicas, contida na parte final do inciso XII, do artigo $5^{\circ}$, da Carta Magna. A sua norma regulamentadora dispõe, em seu artigo $1^{\circ}$, que:

\footnotetext{
Art $1^{\circ}-\mathrm{A}$ interceptação das comunicações telefônicas, de qualquernatureza, para prova em investigação criminal e em instrução processualpenal, observará o disposto nesta Lei e dependerá de ordem do juizcompetente da ação principal, sob segredo de justiça.

Parágrafo único. O disposto nesta Lei aplica-se à interceptação do fluxo decomunicações em sistemas de informática e telemática.
}

entendimento no sentido de reconhecer que "à falta da lei que, nos termos do referido dispositivo [art. $5^{\circ}$, XII, da CF], venha a disciplinar e viabilizar a interceptação de comunicação telefônica contamina outros elementos probatórios eventualmente coligidos, oriundos, direta ou indiretamente, das informações obtidas na escuta" (STF, HC 73351, Rel. Min. Ilmar Galvão, Tribunal Pleno, julgado em 09.05.1996, DJ 19.03.1999). Disponível em: <http://www.stf.jus.br/jurisprudencia>. Acesso em: 10 fev. 2013. 
A possibilidade de obter provas por meio de interceptação telefônica condiciona-se a três requisitos, a saber: deve haver ordem judicial (determinada por um juiz, por iniciativa própria do interessado, ou a requerimento da autoridade policial ou do Ministério Público), a finalidade é a investigação criminal ou a instrução processual penal, e a sua realização observará a forma que a lei estabelecer (o fato investigado deve constituir infração penal punida com reclusão; é exigível a existência de indícios razoáveis da autoria ou participação, ou, ainda, quando aprova não puder ser feita por outros meios).

No dispositivo seguinte (artigo $2^{\circ}$ ), a lei define as hipóteses em que não se reconhece cabível a utilização da interceptação telefônica como meio de obtenção de prova. A escolha do legislador foi a de apontar as circunstâncias em que se exclui a possibilidade de decretação da medida (requisitos negativos). Segundo Vicente Greco Filho, essa técnica legislativa é "lamentável, porque a redação negativa sempre dificulta a intelecção da vontade da lei" (GRECO FILHO, 2005, p. 21), crítica com a qual se concorda, pois se está a tratar, como exceção, o que, em verdade, é a regra - o sigilo das comunicações telefônicas.

Um dos requistos legais a merecer destaque é a inadmissibilidade da interceptação, quando ausentes indícios razoáveis da autoria ou da participação em infração penal, ou, ainda, quando a prova puder ser obtida por outras maneiras legalmente previstas. Tal regramento reflete a concepção de que "especialmente no campo penal, é inconcebível que o Estado banalize os direitos fundamentais para obter provas" (GOMES FILHO, 1996, p. 14). Por esse mesmo motivo, entende-se que a possibilidade de o magistrado decretar a medida, de ofício, é de constitucionalidade duvidosa, uma vez que o julgador, no ordenamento jurídico brasileiro, é, tão somente, o destinatário da prova.

A existência de um fato delituoso concreto é o pressuposto para o deferimento da medida, pois não se cogita do deferimento da medida "numa fase pré-delitual, ou seja, preventiva" (GOMES; CERVINI, 1997, p. 54), ou, ainda, diante de mera suspeita. A respeito da delimitação do objeto a ser investigado, Antonio Scarance Fernandes assinala que:

Uma interpretação rigorosa, que exigisse precisa delimitação da infração, tornaria sem eficácia a lei, iria contra seus próprios objetivos, pois se pretende com ela justamente esclarecer, pela interceptação, a prática delituosa; [sendo] suficiente a delimitação do fato, mas sem a necessidade de minuciosa especificação (FERNANDES, 2007, p. 101).

Em relação à finalidade de instruir investigação policial ou processo criminal, bem como no tocante à exigência de que a infração penal seja punida 
com pena de reclusão, Gustavo Badaró ressalva a possibilidade de que, para além da gravidade das infrações penais, devam ser consideradas as "particularidades da forma de seu conhecimento" (BADARÓ, 2008, p. 287), ou seja, propõe que se questione, no caso concreto, se a interceptação telefônica é o meio hábil à apuração de determinado delito.

Dessa forma, é imprescindível "a indicação concreta de que a reconstrução dos fatos é impossível sem a interceptação telefônica” (BADARÓ, 2008, p 287), pois a viabilidade da utilização de outros meios de obtenção de prova disponíveis para a aferição da materialidade e da autoria do delito retira a legitimidade dessa medida ${ }^{14}$. No entanto, vale referir que já foi reconhecida pelos Tribunais Superiores a possibilidade de utilização do conteúdo da interceptação telefônica, na condição de prova "emprestada", desde que autorizado pelo juízo criminal e que sejam observadas as prescrições da Lei $\mathbf{n}^{0} 9.296 / 1996^{15}$.

A autorização judicial, em virtude de seu caráter vinculado a determinado fato criminoso, deve limitar a quebra do sigilo àqueles agentes relacionados a uma prática delituosa específica. Não se pode olvidar que, "quando se desvia o foco da investigação de um fato, certo e determinado, para abranger qualquer tipo de ilícito que eventualmente tenha praticado o réu, opera-se no campo do substancialismo inquisitorial" (LOPES JÚNIOR, 2012, p. 586), do qual o processo penal contemporâneo pretende se desvincular. Além disso, “o princípio da especialidade e o da vinculação do ato" (LOPES JÚNIOR, 2012, p. 587) também

${ }^{14}$ Traz-se à colação excerto da ementa de julgado do STF: “[...] 1. É da jurisprudência da Corte o entendimento de que 'é lícita a interceptação telefônica, determinada em decisão judicial fundamentada, quando necessária, como único meio de prova, à apuração de fato delituoso' (HC 105.527, Rel. Min. Ellen Gracie, Segunda Turma, DJe de 13.05.2011). 2. No caso, a decisão proferida pelo Juízo de piso, autorizando a interceptação telefônica em questão, encontra-se devidamente fundamentada, sendo os elementos constantes dos autos suficientes para afastar os argumentos dos impetrantes/pacientes de que não havia indícios de materialidade em infração penal para se determinar a quebra do sigilo telefônico ou de que as provas pudessem ser colhidas por outros meios disponíveis, mormente se levado em conta que as negociações das vantagens indevidas solicitadas se davam por telefone" (STF, HC 103418, Rel. Min. Dias Toffoli, Primeira Turma, DJe de11.11.2011). Disponível em: <http://www.stf.jus.br/portal/jurisprudencia/ listarJurisprudencia.asp>. Acesso em: 8 maio 2013.

${ }^{15}$ A esse respeito, é válida a menção ao julgado do Supremo Tribunal Federal que considerou que "os elementos informativos de uma investigação criminal, ou as provas colhidas no bojo de instrução processual penal, desde que obtidos mediante interceptação telefônica, devidamente autorizada por Juízo competente, admitem compartilhamento para fins de instruir procedimento criminal ou mesmo procedimento administrativo disciplinar contra os investigados" (STF, HC 102293, Rel. Min. Ayres Britto, Segunda Turma, DJe de 16.12.2011). No mesmo sentido: STF, Inq. n 2424, Rel. Min.Cezar Peluso, DJe de 25.03.2010. Disponível em: <http://www.stf.jus.br/portal/jurisprudencia/listarJurisprudencia.asp>. Acesso em: 7 maio 2013; e STJ, MS 16.146, Rel. Min. Eliana Calmon, Primeira Seção, julgado em 22.05.2013. Disponível em: <http://www.stf.jus.br/portal/cms/verNoticiaDetalhe.asp>. Acesso em: 28 maio 2013. 
objetivam a salvaguarda do sigilo de terceiro, contra quem a prova adquirida não pode ser utilizada. Tal restrição, logicamente, não se aplica aos casos de coautoria ou participação delitiva, pois, nestas situações, os acusados encontram-se na posição de corréus.

Outro aspecto a ser considerado é que, durante a realização de uma interceptação telefônica, poderá haver a descoberta da prática de delito diverso daquele que originou a autorização da referida medida. Nessa hipótese, deverá ser providenciada a imediata comunicação desse fato, ao juízo que deferiu, inicialmente, a interceptação para que este determine quais as providências serão tomadas para conservar/garantir a validade da prova colhida. A autoridade judiciária decidirá, por exemplo, acerca da necessidade de intervenção via mandado de busca e apreensão, decretação de prisões ou, ainda, sobre eventual pedido de ampliação da medida restritiva, uma vez que o pedido anterior possuía vinculação a fato determinado.

Também merece destaque, quando do exame dos requisitos legais para o deferimento da interceptação telefônica, a competência da autoridade judicial. Em relação a este tópico, deve-se ter mente que a autorização apenas pode ser concedida pelo juiz natural, todavia isso não impede que a prova colhida pela autoridade, à época competente, seja convalidada por aquela para a qual serão remetidos os autos em razão do reconhecimento superveniente de sua competência. Podem ser mencionadas, como exemplo, as situações em que, durante a investigação criminal, surge a notícia de que um dos agentes envolvidos na prática delituosa tenha foro privilegiado.

A esse respeito, a Corte Especial do Superior Tribunal de Justiça, quando do julgamento de ação penal originária, já se manifestou no sentido de que "o envio dos autos ao STJ não invalida qualquer prova colhida ou medida determinada pela autoridade que era então competente para conduzir o inquérito"16. Na mesma linha, o Supremo Tribunal Federal adotou a Teoria do Juízo Aparente para convalidar as provas determinadas por juízo, posteriormente declarado incompetente, desde que, "no momento em que tivessem sido decretadas as medidas de caráter probatório, a autoridade não tivesse condições de saber que a investigação fora instaurada contra detentor de foro privilegiado" ${ }^{917}$. Conclui-se,

16 STJ, APn 536, Rel. Min. Eliana Calmon, Corte Especial, DJe de 04.04.2013. Disponível em: $<$ http://www.stj.jus.br/revistaeletronica>. Acesso em: 1 maio 2013.

${ }_{17}$ Trecho da manifestação do Ministro Celso de Mello, voto vencido no julgamento do Habeas Corpus 110.496. Nesse julgado, a Segunda Turma do Supremo Tribunal Federal não considerou razoável a anulação de provas, determinadas por juízo federal de primeira instância, em investigação que envolvia 
portanto, que usurpação de competência exclusiva, quando reconhecida, invalida a prova colhida.

Em julgado datado de 2 de maio de $2013^{18}$, o Plenário do STF rejeitou a denúncia ofertada contra deputado federal, em face de o juízo de primeiro grau ter autorizado o prosseguimento de investigação, a qual incluía a realização de interceptações telefônicas, mesmo após ter sido verificado o envolvimento do parlamentar denunciado, quando deveria ter havido declinação de competência em favor da Suprema Corte.

De modo semelhante ao contexto acima, em havendo conexão ou continência entre um delito que deva ser julgado pelo juízo federal e outro que seja de competência estadual, por exemplo, o encontro fortuito de provas que provoque o reconhecimento superveniente da incompetência do juízo que autorizou a interceptação, exige-se que seja promovida a comunicação imediata e a posterior remessa dos autos à autoridade reconhecida como competente.

Ainda sobre o encontro fortuito, o Supremo Tribunal Federal considera compatível com o artigo $5^{\circ}$, XII e LVI, “o uso de prova obtida, fortuitamente, através de interceptação telefônica licitamente conduzida, ainda que o crime descoberto, conexo ao que foi objeto da interceptação, seja punido com pena de detenção" ${ }^{\prime 19}$.

\subsection{DO PRAZO DE DURAÇÃO DAS INTERCEPTAÇÕES TELEFÔNICAS}

No que diz respeito à duração das interceptações telefônicas, por força do regramento inserto no artigo $5^{\circ}$, da Lei $n^{\circ} 9.296 / 96$, o prazo máximo da diligência é de 15 (quinze) dias, com possibilidade de renovação, por igual período, caso seja comprovada a necessidade da mantença da medida. Por conseguinte, mostra-se cabível a autorização da interceptação por prazo menor que o supramencionado. A contagem do prazo computa o primeiro dia em que tenha sido iniciada a ingerência.

organização criminosa, direcionada a fraudar benefícios previdenciários, integrada por três vereadores da cidade do Rio de Janeiro, detentores de foro privilegiado perante o TJRJ (HC 110496, Rel. Min. Gilmar Mendes, Segunda Turma, DJe de 18.04.2013. Acórdão pendente de publicação, Informativo 701) Disponível em: <www.http://www.stf.jus.br/portal/jurisprudencia/listarJurisprudencia.asp/Informativo>. Acesso em: 8 maio 2013.

18 Trata-se do julgamento do Inquérito 2842, relativo à denominada "Operação Rodin" (STF, Inq 2842, Rel. Min. Ricardo Lewandowski, Plenário, DJe de 13.05.2013). Disponível em: <http://www.stf.jus. br/portal/cms/verNoticiaDetalhe.asp>. Acesso em: 8 maio 2013.

19 STF, AI 626214 AgR, Rel. Min. Joaquim Barbosa, Segunda Turma, DJe de 07.10.2010. Disponível em: <http://www.stf.jus.br/portal/jurisprudencia/listarJurisprudencia.asp/Informativo>. Acesso em: 8 maio 2013. 
Como mecanismo de restrição a direitos fundamentais, aceitação da possibilidade de quebra do sigilo das comunicações, no ordenamento jurídico brasileiro, está condicionada a um período de tempo determinado. De acordo com Geraldo Prado:

\begin{abstract}
Não há diferença alguma, de ordem prática ou axiológica, entre interceptações telefônicas clandestinas, adotadas pelas forças de segurança que serviram às ditaduras militares do continente, e interceptações telefônicas autorizadas judicialmente, executadas por período significativo e além (e fora) de qualquer controle real, independentemente da intenção daqueles que autorizam e ratificam tais medidas e do seu compromisso real com o Estado de Direito. (PRADO, 2006, p. 12).
\end{abstract}

Em verdade, constitui tarefa inarredável da autoridade judiciária o exercício docontrole sobre a execução da interceptação telefônica. Deste modo, tendo em conta a proporcionalidade, cabe à autoridade judicial, por decisão fundamentada, reiteradamente analisar a permanência dos motivos que o levaram a deferir a produção desse meio de prova.

Como já mencionado, a renovação do prazo de execução da medida, por igual período, demanda a comprovação da indispensabilidade da interceptação telefônica como meio de obtenção de prova. Utiliza-se, como um dos critérios para a aferição da validade do deferimento de sucessivas prorrogações, a relevância desse procedimento para o deslinde de uma ação delituosa complexa, casos em que o esclarecimento dos fatos em apuração demanda um período de tempo maior, decorrente de uma atuação investigativa que ultrapassa o agir usual.

O Supremo Tribunal Federal, em mais de uma oportunidade, posicionou-se no sentido de ser "legítima a prorrogação do prazo para a intercepção telefônica, quando o fato exigir investigação diferenciada e contínua" ${ }^{" 20}$, estabelecendo,

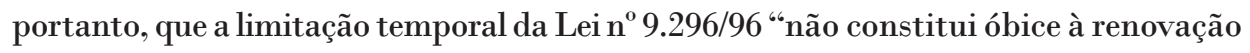
do pedido de interceptação por mais de uma vez se persistirem os pressupostos que o conduziram" ".21. Consideram-se justificadas, portanto, as prorrogações "por períodos sucessivos quando a intensidade e a complexidade das condutas delitivas investigadas assim o demandarem"22.

${ }^{20}$ STF, HC 83.515, Rel. Min. Nelson Jobim, Plenário, DJe de 04.03.2005. Disponível em: <http:// www.stf.jus.br/portal/jurisprudencia/listarJurisprudencia.asp>. Acesso em: 1 abr. 2013.

${ }^{21}$ STF, HC 84301, Rel. Min. Joaquim Barbosa, Segunda Turma, DJe de 24.03.2006. Disponível em: <http://www.stf.jus.br/portal/jurisprudencia/listarJurisprudencia.asp>. Acesso em: 1 abr. 2013.

22 STF, HC 12601, Rel. Min. Dias Toffoli, Primeira Turma, julgado em 04.10.2011, DJe de 24.03.2006. Disponível em:<http://www.stf.jus.br/portal/jurisprudencia/listarJurisprudencia.asp>. Acesso em: 28 out. 2011. 
Nas hipóteses de cometimento de delitos de grande complexidade (lavagem de dinheiro, tráfico de drogas), de difícil comprovação (corrupção ativa e passiva), delitos permanentes (sequestro) ou, ainda, crimes praticados em continuidade delitiva, a prorrogação do prazo de quinze dias, mesmo que sucessivamente, não pode ser considerada, por si só, um ato que viole os ditames do artigo $5^{\circ}$, da Lei $\mathbf{n}^{\circ} 9.296 / 96$.

Em decisões da Primeira Turma do STF, a legitimidade da prorrogação por um período superior a 30 (trinta) dias (quinze dias mais uma prorrogação) foi reconhecida quando "necessária e justificada, circunstancialmente, a utilização prolongada de métodos de investigação invasivos, especialmente se a atividade criminal for igualmente duradoura, nos casos de crimes habituais, permanentes ou continuados"23.

Da leitura do inteiro teor dos julgados acima mencionados, pode-se verificar que a justificativa para a ratificação, por parte da Corte Suprema, das inúmeras prorrogações de interceptações telefônicas foi o reconhecimento da necessidade (subprincípio da proporcionalidade em sentido lato) de se dar prosseguimento às investigações relativas a crimes de alta complexidade como, por exemplo, os delitos cometidos contra o Sistema Financeiro Nacional. Entendeu o Supremo Tribunal Federal que o meio escolhido era omenos grave dentre os eficazes e disponíveis ao fim almejado.

Não é diversa a orientação do Superior Tribunal de Justiça, intérprete da lei federal. Em sede de Recurso Ordinário em Habeas Corpus n 25.268, a Sexta Turma daquela Corte Superior considerou razoável a duração, mediante sucessivas renovações, de um procedimento de interceptação telefônica, que durou cerca de um ano, haja vista terem sido observados "o princípio da razoabilidade e a necessidade da medida para a atividade investigatória, comprovada concretamente em decisão fundamentada" ${ }^{n 4}$.

Por ocasião do julgamento do Habeas Corpus $\mathbf{n}^{\circ} 179.956$, o mesmo colegiado, diante da complexidade da atividade delitiva a ser investigada, reconheceu legítimas as diversas e subsequentes autorizações para a realização de interceptações telefônicas.

${ }^{23}$ STF, HC 99619, Rel. Min. Marco Aurélio, Rel. p/ Acórdão Min. Rosa Weber, Primeira Turma, DJe de 22.03.2012. Disponível em:<http://www.stf.jus.br/portal/jurisprudencia/listarJurisprudencia.asp>. Acesso em: 1 abr. 2013.

${ }^{24}$ STJ, RHC 25268, Rel. Min. Vasco Della Giustina (desembargador convocado do TJ/RS), Sexta Turma, DJe de 11.04.2012. No mesmo sentido: STJ, HC 235.088/DF, Rel. Ministro Campos Marques (desembargador convocado do TJ/PR), Quinta Turma, julgado em 16.04.2013, DJe de 22.04.2013. Disponível em: <http://www.stj.gov.br/portal_stj/publicacao>. Acesso em: 1 maio 2013. 
A Sexta Turma da Corte Suprema considerou suficientemente fundamentadas e, em razão desse entendimento, tidas como legítimas as decisões judiciais que deferiram, reiteradamente, prorrogações do prazo anteriormente concedido. Foram referendadas as manifestações judiciais que, para deferirem as aludidas prorrogações, reproduziam os fundamentos da decisão anterior, pois se entendeu que estava "evidenciada a necessidade da medida, diante da continuação do quadro de imprescindibilidade da providência cautelar" ${ }^{925}$. Tal entendimento foi, inclusive, referendado pelo Órgão Especial daquela Corte ${ }^{26}$.

Contudo, em julgamento emblemático, o Superior Tribunal de Justiça, contrariando a orientação prevalente, interpretou com maior rigidezas disposições da Lei $n^{\circ}$ 9.296/96. Na hipótese em julgamento, estava-se diante da realização de um procedimento de interceptação telefônica que perdurou por mais de dois anos. A despeito de seu caráter excepcional, no caso em questão a medida restritiva havia se tornado rotineira, em flagrante violação do princípio da razoabilidade. Nesse julgado, o relator, Min. Nilson Naves, entendeu como razoável, para fins de prorrogaçãode interceptações telefônicas, o prazo total de 60 (sessenta) diasdesde que "exaustivamente fundamentada" a decisão ${ }^{27}$. O julgador utilizou esse lapso em uma analogia ao período de Estado de Defesa (artigo 136, $§ 2^{\circ}$, da Constituição Federal). Esse julgado, restou, de certa forma, isolado perante as mais recentes decisões do Superior Tribunal de Justiça.

Dada a dificuldade em se estabelecer um parâmetro temporal definitivo, a legitimidade da interceptação telefônicadecorre da observância, por parte da autoridade judicial que a autoriza, ao princípio da proporcionalidade. Como aponta Leandro Cadenas Prado (2009, p. 57), "se em contraposição estão o direito à intimidade e a necessidade de interceptação, não pode o julgador se olvidar da relatividade daquele, mormente quando demonstrada a necessidade do afastamento do direito em comento para o adequado desenrolar da investigação".

O debate perpassa, indubitavelmente, pela suficiência dos fundamentos da decisão judicial que autoriza a interceptação telefônica. Afinal, segundo Antônio Magalhães Gomes Filho, deve-se considerar que:

${ }_{25}$ STJ, HC 179956, Rel. Min. Maria Thereza de Assis Moura, Sexta Turma, DJe de 27.02.2012. Disponível em: <http://www.stj.gov.br/portal_stj/publicacao>. Acesso em: 1 maio 2013.

${ }^{26}$ STJ, APn 536, Rel. Min. Eliana Calmon, Corte Especial, DJe de 04.04.2013. Disponível em: $<$ http://www.stj.gov.br/SCON/jurisprudencia/toc.jsp>. Acesso em: 1 maio 2013.

27 STJ, HC 142.045/PR, Rel. Ministro Celso Limongi (desembargador convocado do TJ/SP),Rel. p/ Acórdão Ministro Nilson Naves, Sexta Turma, julgado em 15.04.2010, DJe de 28.06.2010. Disponível em: <www.stj.jus.br/SCON/jurisprudencia/toc.jsp>. Acesso em: 1 maio 2013. 
Como uma espécie de prestação de contas desse modo de atuar, a motivação das decisões judiciais adquire uma conotação que transcende o âmbito próprio do processo para situar-se, portanto, no plano mais elevado da política, caracterizando-se como um instrumento mais adequado ao controle sobre a forma pela qual se exerce a função jurisdicional. (GOMES FILHO, 2001, p. 78-79).

Faz-se, portanto, necessário lançar mão do princípio da proporcionalidade como referencial para a atividade do intérprete da lei que, diante da necessária ponderação de valores, buscará a compatibilização dos mesmos. Para Luciano Feldens, esse princípio,

sem descurar de seu revestimento normativo - porquanto efetivamente se trata de um dever de proporcionalidade a sobrepairar a atuação dos poderes públicos na prospecção do interesse coletivo em cotejo com os direitos fundamentais - situa-se como ferramenta hermenêutica incorporada ao processo decisório com aptidão bastante a sindicar uma determinada medida assumida para a consecução de um específico fim. (FELDENS, 2005, p. 159-160).

Como se pode concluir, o parâmetro de legitimidade da decisão judicial autorizativa da realização/manutenção da interceptação telefônica é a necessidade (melhor dizendo, imprescindibilidade) de tal medida em face do caso concreto, a qual deve ser o cerne da fundamentação.

\subsection{DA TRANSCRIÇÃO DO CONTEÚDO DOS DIÁLOGOS INTERCEPTADOS}

Por fim, vale ressaltar um aspecto de caráter procedimental - a degravação dos diálogos interceptados. A conversa interceptada deve ser transcrita. Feita a diligência, será elaborado um auto com resumo do que foi obtido, remetendo-se ao juízo a mídia com a gravação relativa ao fato delituoso apurado e sua respectiva transcrição. Se houver dúvidas sobre a autenticidade do material colhido, a prova pericial pode ser deferida pela autoridade judicial ${ }^{28}$. Posteriormente, será determinado o apensamento aos autos, com a determinação de serem destruídas as partes que não forem de interesse ao processo.

Acerca da necessidade de transcrição integral dos diálogos colhidos, a posição predominante nos Tribunais Superiores direciona-se no sentido de reconhecer a sua "desnecessidade, bastando que se permita às partes o acesso à

${ }^{28}$ STJ, HC 189.069, Rel. Min. Laurita Vaz, Quinta Turma, DJe 10.10.2013. Disponível em: <http:// www.stf.jus.br/portal/jurisprudencia/listarJurisprudencia.asp>. Acesso em:22 out. 2013. 
conversação observada"29. Contudo, por ocasião do julgamento da AP $508 \mathrm{AgR}^{30}$, o plenário do Supremo Tribunal Federal, por maioria, negou provimento ao agravo regimental interposto pelo Ministério Público contra decisão do relator que havia determinado a degravação total da mídia eletrônica referente aos diálogos interceptados durante investigação policial. Nesse caso específico, a maioria dos julgadores considerou necessária a transcrição total da comunicação interceptada e não apenas a transcrição de trechos da mesma.

Vale destacar que o entendimento de que é dispensável a transcrição integral dos diálogos está condicionada à disponibilização da mídia correlata para a defesa, em tempo hábil e anterior à realização de audiência, a fím de que não haja prejuízos à atuação da mesma defesa ${ }^{31}$. O Superior Tribunal de Justiça já se manifestou no sentido de considerar razoável o prazo de 02 (dois) dias ${ }^{32}$, não reconhecendo afronta à ampla defesa.

\section{A POSTURA DO CONSELHO NACIONAL DE JUSTIÇA BRASILEIRO EAS PROPOSTAS DE ALTERAÇÃo LEGISLATIVA - PLS 156/2009}

O plenário do Conselho Nacional de Justiça (CNJ) aprovou, em setembro de 2008, a Resolução n ${ }^{\circ} 59 / 2008^{33}$, que regulamentou, no âmbito do Poder Judiciário, a aplicação da Lei $\mathrm{n}^{\circ}$ 9.296/96.

A finalidade da norma infralegal foi a de uniformizar as rotinas, visando ao aperfeiçoamento do procedimento de interceptação no âmbito do Poder Judiciário. O próprio texto da Resolução aponta que sua elaboração decorreu da necessidade de se propiciar ao magistrado uma base para a elaboração de uma decisão com independência e segurança, além de garantir a eficácia da instrução processual, tornando-a confiável e padronizada em todo o território nacional ${ }^{34}$.

29 STJ, HC 235.088, Rel. Min. Campos Marques (desembargador convocado do TJ/PR), Quinta Turma, DJe de 22.04.2013; STF, APn 536, Rel. Min. Eliana Calmon, Corte Especial, DJe de 04.04.2013. Disponível em: <http://www.stj.jus.br/SCON/jurisprudencia/toc.jsp>. Acesso em: 1 maio 2013. Ver ainda: STF, Inq 2774, Rel. Min. Gilmar Mendes, Plenário, DJe de 05.09.2011. Disponível em: <http://www.stf.jus. br/portal/jurisprudencia/listarJurisprudencia.asp>. Acesso em: 12 maio 2013.

${ }^{30}$ STF, AP 508 AgR, Rel. Min. Marco Aurélio, Plenário, julgado em 07-02-2013. Disponível em: <http://www.stf.jus.br/portal/jurisprudencia/listarJurisprudencia.asp>. Acesso em: 12 maio 2013.

31 STF, Inq 2424, Rel. Min. Cezar Peluso, Plenário, DJe de 25.03.2010. Disponível em: <http:// www.stf.jus.br/portal/jurisprudencia/listarJurisprudencia.asp>. Acesso em: 12 maio 2013.

32 STJ, RHC 20472, Rel. Min. Maria Thereza De Assis Moura, Sexta Turma, DJe de 09.11.2009. Disponível em: <http://www.stf.jus.br/portal/jurisprudencia/listarJurisprudencia.asp>. Acesso em: 12 maio 2013.

${ }^{33}$ Disponível em: <http://www.cnj.jus.br/images/stories/docs_cnj/resolucao/rescnj_59.pdf>. Acesso em: 10 maio 2013.

34 Disponível em: <http://www.cnj.jus.br/images/stories/docs_cnj/resolucao/rescnj_59.pdf>.Acesso em: 10 maio 2013. 
Essa Resolução fornece as regras que deverão ser aplicadas nos procedimentos destinados às autorizações judiciais para escutas telefônicas, conforme estabelecido em seu primeiro artigo:

Art. $1^{\circ}$ - As rotinas de distribuição, registro e processamento das medidas cautelares de caráter sigiloso em matéria criminal, cujo objeto seja a interceptação de comunicações telefônicas, de sistemas de informática e telemática, observarão disciplina própria, na forma do disposto nesta Resolução.

Dentre as medidas tomadas, tem-se a exigência de que os pedidos de interceptação encaminhados ao Poder Judiciário estejam em envelopes lacrados, sem identificação e que constem a condição de medida sigilosa. Além disso, os ofícios expedidos às operadoras deverão ser gerados, via sistema informatizado do próprio órgão judicial, contendo a expressa orientação de que não haja monitoramento de números que não integrem a decisão judicial autorizativa.

A Resolução estabelece que cabe aos juízes informarem, mensalmente, às Corregedorias Estaduais e Federais de Justiça, a quantidade de escutas autorizadas. Esses dados servirão de base para uma análise estatística e para o monitoramento quantitativo da utilização desse meio de obtenção de prova em nível nacional.

A regulamentação prevê, ainda, a redução e a limitação do número de intermediários, além da identificação das pessoas que tiveram acesso às escutas autorizadas, medida que reforça a preservação do sigilo das informações obtidas e reduz a probabilidade de "vazamentos", uma vez que estabelece critérios para a manutenção da cadeia de custódia das provas obtidas.

Observa-se, neste contexto, que o conteúdo da Resolução do Conselho Nacional de Justiça tem forte inspiração na Lei $\mathrm{n}^{\circ}$ 8.159/91, que dispõe sobre a política nacional de arquivos públicos e privados. A retrocitada norma estipula o modo de conservação de informações, bem como a maneira de preservar a integridade do meio no qual estas se encontram abrigadas (meio eletrônico ou multimídia, na grande maioria). Vale fazer referência ao artigo $3^{\circ}$ do diploma legal acima mencionado:

Art. $3^{\circ}$ - Considera-se gestão de documentos o conjunto de procedimentos e operações técnicas à sua produção, tramitação, uso, avaliação e arquivamento em fase corrente e intermediária, visando a sua eliminação ou recolhimento para guarda permanente.

Com o advento da Lei $\mathrm{n}^{\circ} 12.527 / 2001^{35}$, especificamente nos artigos $25 \mathrm{e}$

${ }^{35}$ Disponível em: <http://www.planalto.gov.br/ccivil_03/_Ato2011-2014/2011/Lei/L12527.htm>. Acesso em: 11 maio 2013. 
26, estabeleceu-se como dever do Estado o controle do acesso e da divulgação de informações sigilosas produzidas por seus órgãos e entidades, assegurando a sua proteção. Há, ainda, a determinação de que cabe às autoridades públicas adotar as providências necessárias para que seus subordinados tomem conhecimento e passem a adotar as medidas e procedimentos de segurança exigidos no tratamento desse tipo de informação.

No que concerne ao lapso temporal previsto para o andamento do procedimento de interceptação telefônica, a orientação dada pelo CNJ é a de que o juiz examine, prudentemente, as argumentações da autoridade solicitante no seu expediente postulatório e, em momento posterior, estipule, de forma expressa na sua decisão, o tempo em que a interceptação determinada perdurará, fazendo constar, ainda, a vedação expressa da inclusão de outros números que não aqueles discriminados na decisão.

O que se percebe é que, ao detalhar e regulamentar os procedimentos cartoriais, o CNJ pretende garantir a validade da prova colhida por meio da interceptação telefônica, buscando reduzir eventuais enganos, fraudes, zelando pela eficiência e pela lisura do procedimento. Houve um arranjo organizacional para a consolidação e efetivação dessa normativa, propondo-se uma atuação metódica e coordenada entre os entes envolvidos na produção da prova. Vale lembrar que a efetivação da medida não envolve somente os agentes do Estado, uma vez que necessita, também, da participação das operadoras de serviço de telefonia.

Embora essa Resolução tenha sido aprovada pela quase totalidade de Conselheiros, houve divergência do Conselheiro Felipe Locke Cavalcanti ${ }^{36}$, que entendeu que essa norma não resolve o problema das escutas ilegais e que caberia exclusivamente ao Congresso Nacional a regulamentação de forma mais ampla e profunda.

As ações do Conselho Nacional de Justiça abrangem, inclusive, pronunciamentos sobre anteprojetos de lei de interesse do Poder Judiciário, como, por exemplo, o projeto de lei que trata de um novo Código de Processo Penal.

O Projeto de Lei do Senado (PLS) 156/2009, que trata da reforma do Código de Processo Penal, abarca o procedimento de interceptação telefônica, cuja normatização atual se dá por meio da legislação própria. No Livro I (Da persecução penal), Capítulo III (Dos meios de obtenção de prova), Seção III, encontra-se a proposta de regramento relativo às interceptações telefônicas, com regras gerais e um rol de atos a serem observados na realização desse procedimento.

${ }^{36}$ Conforme Ata e Certidão de Julgamento. Disponível em: <http://www.cnj.jus.br/index.php>. Acesso em: 11 maio 2013. 
A redação final do artigo 245, do PLS 156/09, traz um regramento de caráter genérico, que se assemelha à descrição do artigo $1^{\circ}$, da Lei $n^{\circ}$ 9.296/96.

Já no que diz respeito ao artigo 246 do Projeto $^{37}$, a inovação que merece destaque é a inclusão de outras categorias até então não incluídas no conceito de interceptação - as escutas e das gravações, as quais passam a ser submetidas ao idêntico tratamento jurídico.

Em se tratando de infrações penais de menor potencial ofensivo, não terá cabimento a utilização desse meio de obtenção de prova, excetuadas as hipóteses em que a prática delitiva seja realizada exclusivamente por esse meio de comunicação ${ }^{38}$.

A autoridade competente para apreciar o pedido de interceptação, feito por escrito $^{39}$, será o juiz de garantias, o qual zelará pela legalidade durante o procedimento investigatório, sendo que os legitimados para requererem a autorização serão o Ministério Público, a defesa e a autoridade policial, ouvido o órgão ministerial. Essa proposta de alteração legislativa não deixa margem a debates acerca da possibilidade de que o juiz, de ofício, determine a produção dessa prova ${ }^{40}$, redação precisa que se mostra acertada por estar em conformidade com o princípio do contraditório e o da ampla defesa.

$O$ juiz de garantias ${ }^{41}$, figura prevista no artigo 14 do Projeto de Lei, é a

${ }^{37}$ Dispõe o artigo 246, do Projeto de Reforma do Código de Processo Penal: "Art. 246 - O sigilo das comunicações telefônicas compreende o conteúdo de conversas, sons, dados e quaisquer outras informações transmitidas ou recebidas no curso das ligações telefônicas. $\S^{\circ}$ Considera-se interceptação das comunicações telefônicas a escuta, gravação, transcrição, decodificação ou qualquer outro procedimento que permita a obtenção das informações e dados de que trata o caput deste artigo. $2^{\circ}$ Quanto aos registros de dados estáticos referentes à origem, destino, data e duração das ligações telefônicas, igualmente protegidos por sigilo constitucional, observar-se-ão as disposições do Capítulo III, Seção II, Título VIII, deste Livro". Disponível em: <http://www.senado.gov.br/atividade/materia/getPDF.asp?t=85509\&tp=1.asp >. Acesso em: 12 ago. 2013.

${ }^{38}$ Nos termos da redação dada ao artigo 247, do PLS 156/2009. Disponível em: <http://www. senado.gov.br/atividade/materia/getPDF.asp?t=85509\&tp=1.asp>. Acesso em: 12 ago. 2013.

39 O pedido verbal é exceção.

${ }_{40}$ Possibilidade prevista na Lei ${ }^{\circ}$ 9.296/96 e objeto de ADI 4112.

${ }^{41}$ Nos termos da Exposição de Motivos elaborada pela Comissão de Juristas: "Para a consolidação de um modelo orientado pelo princípio acusatório, a instituição de um juiz de garantias, ou, na terminologia escolhida, de um juiz das garantias, era de rigor. Impende salientar que o anteprojeto não se limitou a estabelecer um juiz de inquéritos, mero gestor da tramitação de inquéritos policiais. Foi, no ponto, muito além. O juiz das garantias será o responsável pelo exercício das funções jurisdicionais alusivas à tutela imediata e direta das inviolabilidades pessoais. A proteção da intimidade, da privacidade e da honra, assentada no texto constitucional, exige cuidadoso exame acerca da necessidade de medida cautelar autorizativa do tangenciamento de tais direitos individuais. $\mathrm{O}$ deslocamento de um órgão da jurisdição com 
autoridade com competência para atuar durante o inquérito policial. Essa figura tem sua razão de ser em face da necessidade de se desvincular o magistrado que decidirá o processo daquele que preside a instrução criminal, tudo isso com a finalidade de evitar a "contaminação" (pré-concepção) do julgador decorrente do fato de ter entrado em prévio contato com a prova, ainda na fase pré-processual.

A execução do procedimento de interceptação sofrerá fiscalização direta do Ministério Público e, após seu encerramento, será o feito remetido à autoridade, acompanhado de um Auto Circunstanciado, no qual serão detalhadas todas as operações realizadas, sendo inutilizado, após sessenta dias, o material que não interessar ao processo ${ }^{42}$.

Em relação ao prazo, contínuo e ininterrupto, de duração da medida, o projeto estabelece um limite de 60 (sessenta) dias, sendo permitidas prorrogações por igual período até limite de 180 (cento e oitenta) dias ininterruptos. As exceções legais dizem respeito aos delitos permanentes, enquanto não cessada a permanência $^{43}$. Para Rafael Júnior Soares, a proposta anterior de limitar o prazo a 360 (trezentos e sessenta) dias mostrava-se excessiva, uma vez que a medida tem caráter excepcional "não se justificando sua manutenção por lapso temporal tão longo, ante a possibilidade de configuração de verdadeira devassa na vida do cidadão, mormente se examinada sob o prisma da proporcionalidade" (SOARES, 2012 , p. 9). O debate a esse respeito encontra-se apenas iniciado, mas a adoção do limite máximo de 180 (cento e oitenta) dias parece estar em consonância com as exigências da proporcionalidade.

Quanto às condutas exigidas pelas empresas prestadoras de serviços, o projeto é mais amplo do que a atual legislação vigente, pois estabelece determinadas

função exclusiva de execução dessa missão atende a duas estratégias bem definidas, a saber: a) a otimização da atuação jurisdicional criminal, inerente à especialização na matéria e ao gerenciamento do respectivo processo operacional; e b) manter o distanciamento do juiz do processo, responsável pela decisão de mérito, em relação aos elementos de convicção produzidos e dirigidos ao órgão da acusação" Disponível em: <http:// www.senado.gov.br/atividade/materia/detalhes.asp>. Acesso em: 12 maio 2013.

42 Segundo a redação dos artigos 255 e 256 do PLS 156/2009. Disponível em: <http://www.senado. gov.br/atividade/materia/getPDF.asp?t=85509\&tp=1>. Acesso em: 12 maio 2013.

43 Faz-se referência ao texto integral do dispositivo: "Art. 252 - O prazo de duração da interceptação não poderá exceder a 60 (sessenta) dias, permitida sua prorrogação por igual período, desde que continuem presentes os pressupostos autorizadores da diligência, até o máximo de 180 (cento e oitenta) dias ininterruptos, salvo quando se tratar de crime permanente, enquanto não cessar a permanência. $§ 1^{\circ} \mathrm{O}$ prazo correrá de forma contínua e ininterrupta e será contado a partir da data do início da interceptação, devendo a prestadora responsável comunicar imediatamente este fato ao juiz, por escrito. $\S 2^{\circ}$ Para cada prorrogação será necessária nova decisão judicial fundamentada, observado o disposto no caput deste artigo". Disponível em: <http:/www.senado.gov.br/atividade/materia/getPDF.asp?t=85509\&tp=1.asp>. Acesso em: 12 maio 2013 . 
condutas a serem exigidas dessas empresas ${ }^{44}$, tais como a disponibilização gratuita de recursos e meios tecnológicos necessários à interceptação, indicando ao juiz o nome do profissional que prestará tal colaboração; a necessidade de ser observado o prazo máximo de 24 (vinte e quatro) horas para o efetivo cumprimento da diligência, sob pena de multa e demais sanções cabíveis. Outro ponto importante é o estabelecimento do dever de informar ao juízo qualquer espécie de suspensão, alteração (portabilidade, por exemplo) ou cancelamento dos serviços em até 24 (vinte e quatro) horas da ciência desse fato.

Sobre o acesso a todo o conteúdo dos diálogos interceptados, após o encerramento da diligência, o magistrado o remeterá ao Ministério Público para que se manifeste sobre a necessidade ou não de diligências complementares em 10 (dez) dias e, ainda, intimará o investigado ou acusado para que se manifeste, fornecendo-lhe cópia identificável do material produzido exclusivamente em relação à sua pessoa ${ }^{45}$.

Já a redação do artigo $260^{46}$ adota escrita semelhante à Súmula Vinculante $\mathbf{n}^{\text {o }} 14$ do Supremo Tribunal Federal ${ }^{47}$, mas de uma forma mais ampla, pois contempla, como regra, a obrigação de que sejam cientificados todos os indivíduos que tiveram suas comunicações gravadas, excepcionada a hipótese de o julgador reputar necessário o sigilo desse material em razão da existência de outras investigações.

De sua vez, o artigo 250 do Projeto tratou do encontro de provas relativas a crime diverso e não conexo ao delito investigado, situação em que “a autoridade deverá remeter ao Ministério Público os documentos necessários

${ }^{44}$ Cf. artigo 254, do PLS 156/2009. Disponível em: < http://www.senado.gov.br/atividade/materia/ detalhes.asp>. Acesso em: 12 maio 2013.

45 Cf. artigo 258, do PLS 156/2009.Disponível em: <http://www.senado.gov.br/atividade/materia/ detalhes.asp>. Acesso em: 12 maio 2013.

${ }^{46}$ Dispõe o artigo 260, do Projeto de Reforma do Código de Processo Penal: "Finda a instrução processual, dar-se-á ciência a todas as pessoas que tiveram conversas telefônicas interceptadas, tenham ou não sido indiciadas ou denunciadas, salvo se o juiz entender, por decisão fundamentada, que a providência poderá prejudicar outras investigações em curso". Disponível em: <www.senado.gov.br/atividade/materia/ detalhes.asp>. Acesso em: 12 maio 2013.

${ }^{47}$ Eis o teor da Súmula Vinculante $\mathbf{n}^{\circ}$ 14: “É direito do defensor, no interesse do representado, ter acesso amplo aos elementos de prova que, já documentados em procedimento investigatório realizado por órgão com competência de polícia judiciária, digam respeito ao exercício do direito de defesa". Disponível em: <www.stf.jus.br/arquivo/cms/jurisprudenciaSumulaVinculante/anexo/PSV_l.pdf>. Acesso em: 12 maio 2013. 
para as providências cabíveis" ${ }^{98}$. Essa proposta busca evitar o prosseguimento de investigação relativa a crime não incluso na decisão autorizativa e sob a supervisão de autoridade incompetente para tanto. A esse respeito, seria válida a existência de uma disposição específica acerca de investigados detentores de foro privilegiado, regramento que auxiliaria, sobremaneira, a mantença da validade da prova obtida.

Em relação ao Projeto de Lei de Reforma do Código de Processo Penal (PLS 156/2009), o Conselho Nacional de Justiça, em sessão plenária realizada em de 17 de agosto de 2010, aprovou uma Nota Técnica (NT no 10/2010). As ponderações relacionadas à interceptação telefônica constam do item 17, abaixo reproduzido:

A matéria relativa à interceptação telefônica até hoje foi objeto de lei própria (Lei 9.296/96). Releva ressaltar que a proposta de inserção da matéria no Projeto de Código de Processo Penal, primeiramente, destoa da sistemática usual, porquanto outras técnicas especiais de investigação como colaboração premiada, ação controlada, captação ambiental e infiltração de agentes são tratados em lei extravagante. Em segundo lugar, a proposta deixou de analisar uma lacuna existente quanto à disponibilização comercial de criptografia na comunicação telefônica, o que tem se mostrado uma grande barreira para a obtenção de informações relevantes para a investigação criminal. Esse ponto, bem como o atual desenvolvimento, pela Polícia Federal, de sistema que garantirá maior segurança e facilitará esse tipo de atividade, deve ser alvo de um grande debate na legislação específica, entre Anatel, empresas de telefonia, fabricantes de aparelhos telefônicos, polícia e sociedade civil. Em terceiro plano, cumpre referir que o projeto também não aborda a imposição de restrições à comercialização de instrumentos tecnológicos (equipamentos e programas) que digam respeito diretamente a ingerências sobre direitos fundamentais do cidadão. Assim, é conveniente excluir do projeto a regulamentação da interceptação telefônica, relegando o tema a amplo debate em legislação extravagante.

Nota-se que, não obstante os questionamentos do referido Conselho contribuam, de forma valiosa, para um aperfeiçoamento do texto do PLS 156/2009, há que se frisar que não se tem notícia da existência de uma discussão mais ampla e escorreita sobre o tema. Parece ser tradição no processo legislativo brasileiro o menosprezo a debate acerca da irrenunciável compatibilização entre a admissibilidade do uso de ferramentas tecnológicas que facilitem a obtenção de provas em processo penal, a necessidade de uma normatização mais detalhada dos procedimentos a serem desenvolvidos e o direito a um processo justo.

${ }^{48}$ Cf. artigo 250, do PLS 156/2009. Disponível em: <http://www.senado.gov.br/atividade/materia/ detalhes.asp>. Acesso em: 12 maio 2013. 
Diante de seu conteúdo decisório, é imprescindível a motivação doato judicial que autoriza a realização e a prorrogação da interceptação telefônica. A indispensabilidade da utilização desse meio de prova condiciona, pois, sua validade.

O parâmetro de legitimidade da decisão judicial autorizativa da realização/ manutenção da interceptação telefônica é a necessidade (melhor dizendo, imprescindibilidade) objetivamente fundamentadade tal medida em face do caso concreto. Em razão disso, persiste a dificuldade de se estabelecer um critério temporal estanque e definitivo.

Faz-se possível concluir que o vetor hermenêutico adotado tanto pelo Supremo Tribunal Federal como pelo Superior Tribunal de Justiça para aferir a validade dainterceptação telefônica é o princípio da proporcionalidade (e seus subprincípios: necessidade, adequação e proporcionalidade em sentido estrito $)^{49}$, acompanhados do princípio da motivação das decisões judiciais e do princípio da ampla defesa.

Ao mesmo tempo, os requisitos legais, tais como a existência de indícios de autoria, a imprescindibilidade da medida cautelar como único meio para a demonstração da materialidade do delito, a observância à competência da autoridade judicial que a defere e a necessidade de se justificar a fixação do prazo e de suas prorrogações, são as condicionantes mais específicas da licitude da prova obtida via interceptação telefônica.

Por derradeiro, verifica-se que a necessidade de inovação/alteração da legislação brasileira, direcionada a especificar e explicitar o modo como será realizado esse procedimento, é inadiável, mas o debate perpassa, necessariamente, pela observância dos princípios constitucionais penais e processuais penais, especialmente o princípio da legalidade, do devido processo legal e da inadmissibilidade de provas ilícitas.

\section{REFERÊNCIAS}

ALEXY, Robert. Teoria de los derechos fundamentales. Madrid: Centro de Estudios Constitucionales, 1993.

AVOLIO, Luiz Fernando Torquato. Provas ilícitas: interceptações telefônicas, ambientais e gravações clandestinas. 4. ed. São Paulo: Revista dos Tribunais, 2003.

BADARÓ, Gustavo Henrique. Direito Processual Penal. Tomo I. Rio de Janeiro: Campus, 2008.

49 Segundo lição de Ingo Sarlet, "a adequação tem o sentido de controle da viabilidade (idoneidade técnica); a necessidade respeita à exigência de opção pelo meio menos restritivo, menos gravoso para o direito objeto de restrição, e a proporcionalidade em sentido estrito concerne à proporção dos meios utilizados e os fins colimados" (SARLET, 2010, p. 101). 
CARRIÓ, Alejandro. Garantías constitucionales en el proceso penal. 4.ed. Buenos Aires: Hammurabi, 2003.

FERNANDES, Antonio Scarance. Processo penal constitucional. 5. ed. São Paulo: Revista dos Tribunais, 2007.

FELDENS, Luciano. A constituição penal: a dupla face da proporcionalidade no controle das normas penais. Porto Alegre: Livraria do Advogado, 2005.

GIACOMOLLI, Nereu José. Reformas (?) do processo penal. Rio de Janeiro: Lumen Juris, 2008. GOMES, Luiz Flávio; CERVINI, Raul. Interceptação telefônica. São Paulo: RT, 1997.

GOMES FILHO, Antônio Magalhães. A motivação das decisões penais. São Paulo: Revista dos Tribunais, 2001.

A violação do princípio da proporcionalidade pela Lei 9.296/96. Boletim do Instituto Brasileiro de Ciências Criminais, n. 45, ago 1996.

GRECO FILHO, Vicente. Interceptação telefônica: considerações sobre a Lei 9.296. 2. ed. São Paulo: Saraiva, 2005.

GRINOVER, Ada Pellegrini. Liberdades públicas e processo penal: as interceptações telefônicas. 2. ed. São Paulo: Revista dos Tribunais, 1982.

LOPES JÚNIOR, Aury. Direito Processual Penal e sua conformidade constitucional. 9. ed. São Paulo: Saraiva, 2012.

MENDES, Gilmar Ferreira; COELHO, Inocêncio; BRANCO, Paulo. Curso de Direito Constitucional. 4. ed. São Paulo: Saraiva, 2007.

PRADO, Geraldo. Limite às interceptações telefônicas e a jurisprudência do STJ. Rio de Janeiro: Lumen Juris, 2006.

PRADO, Leandro Cadenas. Provas ilícitas: teoria e interpretação dos tribunais superiores. 2. ed. Niterói: Impetus, 2009.

SARLET, Ingo Wolfgang. Constituição e proporcionalidade: o direito penal e os direitos fundamentais entre a proibição de excesso e da insuficiência. Revista Brasileira de Ciências Criminais, ano 18, n. 82, jan-fev 2010.

SOARES, Rafael Júnior. Reflexões sobre o prazo de duração da interceptação telefônica no PL 156/2009. Boletim Instituto Brasileiro de Direito Processual Penal, ano 2, n. 2, 2012/01.

STRECK, Lendo Luiz. As interceptações telefônicas e os direitos fundamentais. 2. ed. Porto Alegre: Livraria do Advogado, 2001.

VALENTE, Manuel Monteiro Guedes. Escutas telefônicas: da excepcionalidade à vulgaridade.

2. ed. Coimbra: Almedina, 2008. 